\title{
HUBUNGAN SOSIAL EKONOMI DAN KARAKTERISTIK IBU DENGAN KEJADIAN STUNTING PADA ANAK BALITA
}

\author{
Ismed Krisman Amazihono ${ }^{1}$, Evi Martalinda Harefa ${ }^{2}$ \\ Program Studi Keperawatan Gunungsitoli Poltekkes Kemenkes Medan ${ }^{12}$ \\ email : ${ }^{1}$ ismawatipertiw@gmail.com,2evimartalindaharefa@yahoo.com
}

\begin{abstract}
Stunting is a failure growth condition of children (under five aged) caused by chronic malnutrition so the children is too short for their age. Malnutrition occurs since the baby still unborn and in the early period after the baby born but stunting condition appears after the baby 2 years old. Now days, stunting is one of nutritional problems experienced by the children in the world, Indonesia, North Sumatera and Gunungsitoli town. Stunting needs special attention because it can hamper physical growth, mental development and health status of children.Based on literature study, it was found several factors could cause stunting towards the children such as socioeconomic including education, occupation, income and maternal characteristics including age, knowledge, number of children, supplementary feeding. The research purposed is to know the relationship socioeconomic (education, occupation, income) and maternal characteristics (age, knowledge, number of children, supplementary feeding) with the incidence of stunting towards the children in Hiliweto Idanoi at working area UPTD Puskesmas Gunungsitoli Idanoi sub district in 2020. Research method is quantitative method with cross sectional design. The population in this research are 63 mothers who have children (toddlers) in Hiliweto Idanoi Village by using total sampling technique. The analysis in this research is chi square analysis, if not eligible must be replaced with alternative test namely fisher's exact test (table $2 \times 2$ ), Kolmogorov smirnov test (table $2 \times$ K) or a combination of cell (table other than $2 \times 2$ and $2 \times K$ ). The result showed that there was a relationship income, occupation, number of children and supplementary feeding with the incidence of stunting where the result of the significant value were 0.001, 0, 025, 0.030 and 0.000 and there was no relationship education, knowledge and aged with the incidence of stunting where the result of significant value were 0.418, 0.197, 0.493.

Keywords : Socioeconomic, Maternal Characteristic, Stunting, children nutrition

Bibliography : $29(2009-2019)$
\end{abstract}

\begin{abstract}
ABSTRAK
Stunting adalah kondisi gagal tumbuh pada anak BALITA ( Bayi Dibawah Lima Tahun) akibat dari kekurangan gizi kronis sehingga anak terlalu pendek untuk usianya. Kekurangan gizi terjadi sejak bayi dalam kandungan dan pada masa awal setelah bayi lahir akan tetapi kondisi stunting baru nampak setelah bayi berusia 2 tahun. Stunting merupakan salah satu masalah gizi yang dialami oleh balita baik di dunia, Indonesia, Sumatera Utara dan di Kota Gunungsitoli saat ini. Stunting pada balita perlu mendapatkan perhatian khusus karena dapat menyebabkan terhambatnya pertumbuhan fisik, perkembangan mental dan status kesehatan pada anak. Berdasarkan studi literature ditemukan beberapa faktor yang dapat menyebabkan stunting pada anak antara lain sosial ekonomi meliputi pendidikan, pekerjaan, pendapatan dan karakteristik ibu meliputi umur, pengetahuan, jumlah anak, pemberian makanan tambahan. Tujuan penelitian adalah untuk mengetahui hubungan sosial ekonomi (pendidikan, pekerjaan, pendapatan) dan karakteristik ibu (umur, pengetahuan, jumlah anak, pemberian makanan tambahan) dengan kejadian stunting pada anak Balita di Desa Hiliweto Idanoi Wilayah Kerja UPTD Puskesmas Kecamatan Gunungsitoli Idanoi tahun 2020. Metode penelitian yang digunakan adalah secara kuantitatif dengan desain cross sectional. Populasi penelitian adalah seluruh ibu yang memiliki Balita di desa Hiliweto Idanoi yaitu berjumlah 63 orang, dengan teknik pengambilan sampel yaitu total sampling. Analisis yang digunakan adalah analisis chi square, jika tidak memenuhi syarat harus diganti dengan uji alternatifnya yaitu fisher's exact test (tabel $2 \times 2$ ), uji Kolmogorov smirnov ( tabel $2 \times \mathrm{K}$ ) atau penggabungan sel ( tabel selain $2 \times 2$ dan $2 \times \mathrm{K}$ ). Hasil penelitian menunjukkan adanya hubungan pendapatan, pekerjaan, jumlah anak dan pemberian makanan tambahan dengan kejadian stunting dimana hasil nilai significancy masing - masing adalah 0,001, 0, 025, 0,030 dan 0,000 dan tidak terdapat hubungan pendidikan, pengetahuan dan umur dengan kejadian stunting dimana hasil nilai significancy masing - masing adalah 0,418, 0,197 dan 0, 493.
\end{abstract}

Kata kunci : Sosial Ekonomi, Karakteristik Ibu, Stunting, Gizi Anak Balita.

Daftar Pustaka : $29(2009-2019)$ 


\section{PENDAHULUAN}

\section{Latar Belakang (Opsional)}

Stunting adalah kondisi gagal tumbuh pada anak bayi dibawah lima tahun akibat dari kekurangan gizi kronis sehingga anak terlalu pendek untuk usianya. Kekurangan gizi terjadi sejak bayi dalam kandungan dan pada masa awal setelah bayi lahir akan tetapi kondisi stunting baru terlihat setelah bayi berusia 2 tahun. ${ }^{25}$

Stunting merupakan salah satu masalah gizi yang dialami oleh balita di dunia saat ini. Pada tahun $2017,22,2 \%$ atau sekitar 150,8 juta balita di dunia mengalami stunting, lebih dari setengah balita stunting di dunia berasal dari Asia (55\%) sedangkan lebih dari sepertiganya (39\%) tinggal di Afrika. Dari 83,6 juta balita stunting di Asia, proporsi terbanyak berasal dari Asia Selatan $(58,7 \%)$ dan proporsi paling sedikit di Asia Tengah (0,9\%). Dari data prevalensi balita stunting yang dikumpulkan oleh World Health Organization (WHO), Indonesia termasuk ke dalam negara ketiga dengan prevalensi tertinggi di wilayah Asia Tenggara dimana rata-rata prevalensi balita stunting di Indonesia tahun 2005-2017 adalah 36,4\%.15

Kejadian balita stunting merupakan masalah gizi utama yang dihadapi Indonesia saat ini. Berdasarkan data Pemantauan Status Gizi, stunting memiliki prevalensi tertinggi dibandingkan dengan masalah gizi lainnya seperti gizi kurang, kurus, dan gemuk. Prevalensi balita stunting mengalami peningkatan dari tahun 2015 yaitu sebesar 29\%, kemudian tahun 2016 mengalami penurunan yaitu sebesar $27,5 \%$ dan meningkat kembali sebesar 29,6\% pada tahun 2017. Dari Hasil Riset Kesehatan Dasar (Riskesdas) tahun 2018 menunjukkan prevalensi balita stunting di Indonesia sebesar 30,8 \% hal ini menunjukkan adanya peningkatan dari tahun sebelumnya (Pusdatin, 2018). Dari Hasil Riset Kesehatan Dasar juga diketahui bahwa Provinsi Sumatera Utara menduduki peringkat 13 sebagai penyumbang balita stunting di Indonesia. ${ }^{9}$

Berdasarkan hasil pemantauan status gizi di Sumatera Utara diperoleh data peningkatan prevalensi stunting dalam 3 tahun terakhir yaitu di tahun 2016 sebesar 24,4 \%, ditahun 2017 sebesar 28,4\%, dan ditahun 2018 meningkat kembali sebesar 32,4\%. Dari hasil pemantauan status gizi, Kota Gunungsitoli berada diperingkat 5 penyumbang Balita Stunting di Sumatera Utara. $^{10}$

Data yang diperoleh dari Dinas Kesehatan Kota Gunungsitoli menunjukkan prevalensi stunting di Kota Gunungsitoli mengalami penurunan yaitu sebesar 35,8 $\%$ ditahun 2017 menjadi 9,8 \% ditahun 2018. Dari 6 wilayah kerja Dinas Kesehatan Gunungsitoli ditemukan Desa Hiliweto Idanoi merupakan wilayah kerja UPTD Puskesmas Gunungsitoli Idanoi menyumbangkan persentasi tertinggi jumlah Balita stunting yaitu dari 88 Balita ada 26 Balita $(29,55 \%)$ yang mengalami stunting pada tahun 2019 (Profil Kesehatan Kota Gunungsitoli, 2019). ${ }^{11}$
Berdasarkan studi literature yang telah dilakukan ditemukan banyak faktor yang dapat menyebabkan stunting pada anak antara lain faktor sosial ekonomi meliputi pendapatan, pekerjaan, pendidikan dan karakteristik ibu meliputi umur, pemberian makanan tambahan, pengetahuan dan jumlah anak.

Pendapatan keluarga berkaitan dengan kemampuan rumah tangga tersebut dalam memenuhi kebutuhan hidup baik primer, sekunder, maupun tersier. Pendapatan keluarga yang tinggi memudahkan dalam memenuhi kebutuhan hidup, sebaliknya pendapatan keluarga yang rendah lebih mengalami kesulitan dalam memenuhi kebutuhan hidup. Pendapatan yang rendah akan mempengaruhi kualitas maupun kuantitas bahan makanan yang dikonsumsi oleh keluarga. Makanan yang di dapat biasanya akan kurang bervariasi dan sedikit jumlahnya terutama pada bahan pangan yang berfungsi untuk pertumbuhan anak seperti sumber protein, vitamin, dan mineral, sehingga meningkatkan risiko kurang gizi. Keterbatasan tersebut akan meningkatkan risiko seorang balita mengalami stunting. ${ }^{29}$ Hal ini sesuai dengan penelitian yang dilakukan oleh Eko dkk dimana hasil penelitian menyatakan bahwa ada hubungan tingkat pendapatan keluarga dengan kejadian stunting. ${ }^{5}$

Menurut UNICEF dalam BAPPENAS (2011), pekerjaan orang tua merupakan faktor tidak langsung yang mempengaruhi stunting. ${ }^{23}$ Faktor ibu yang bekerja nampaknya belum berperan sebagai penyebab utama masalah gizi anak, namun pekerjaan ini lebih disebut sebagai faktor yang mempengaruhi dalam pemberian makanan, zat gizi, dan pengasuhan/perawatan anak. Ibu yang bekerja diluar rumah cenderung memiliki waktu yang lebih terbatas untuk melaksanakan tugas rumah tangga dibandingkan ibu yang tidak bekerja, oleh karena itu pola pengasuhan anak akan berpengaruh dan pada akhirnya pertumbuhan dan perkembangan anak juga akan terganggu. ${ }^{12}$ Hal ini sesuai dengan penelitian yang dilakukan oleh Sri Mugianti (2018) dimana hasil penelitiannya menyatakan bahwa ibu bekerja merupakan salah satu faktor penyebab stunting. ${ }^{23}$

Tingkat pendidikan mempengaruhi seseorang dalam menerima informasi. Orang dengan tingkat pendidikan yang lebih baik akan lebih mudah dalam menerima informasi dari pada orang dengan tingkat pendidikan yang kurang. Informasi tersebut dijadikan sebagai bekal ibu untuk mengasuh balitanya dalam kehidupan sehari- hari. ${ }^{2}$ Latar belakang pendidikan orang tua, baik ayah maupun ibu, merupakan salah satu unsur penting dalam menentukan status gizi anak. Pendidikan ibu disamping merupakan modal utama dalam menunjang perekonomian rumah tangga, juga berperan dalam pola pemberian makan keluarga maupun pola pengasuhan anak. ${ }^{14}$ Berdasarkan hasil penelitian yang dilakukan oleh Luh Masrini diperoleh hasil bahwa tingkat pendidikan merupakan salah satu faktor yang mempengaruhi kejadian stunting. ${ }^{13}$ 
Umur adalah lamanya waktu hidup yaitu terhitung sejak lahir sampai dengan sekarang. Penentuan umur dilakukan dengan menggunakan hitungan tahun (Chaniago, 2002 ). Menurut Hurlock (1998) semakin cukup umur, tingkat kematangan dan kekuatan seseorang akan lebih matang dalam berfikir dan bekerja. Pernikahan dini yang merupakan pernikahan sebelum usia 18 tahun dapat berdampak buruk terhadap kesehatan ibu dan balita. Anak yang lahir dari ibu yang menikah dini memiliki kesempatan hidup yang rendah dan lebih besar memiliki masalah gizi pada anaknya seperti pendek, kurus, dan gizi buruk. Hal tersebut kemungkinan bisa terjadi karena ibu balita yang umurnya kurang dari 18 tahun biasanya memiliki pola asuh terhadap anaknya kurang baik, pola asuh yang kurang baik tersebut dapat berdampak pada status gizi anaknya. Pada penelitian yang dilakukan Tin Afifah menunjukkan bahwa persentase anak pendek meningkat pada ibu yang menikah pada usia dini. Semakin muda usia pernikahan ibu, maka proporsi balita dengan status gizi pendek semakin meningkat. ${ }^{17}$

Pemberian makanan tambahan kepada ibu hamil merupakan salah satu cara untuk mengatasi kekurangan energi dan protein kronis yang dapat mengakibatkan pertumbuhan fisik balita pendek (stunting)(Kementerian Desa, Pembangunan Daerah Tertinggal Dan Transmigrasi, 2017). Dengan pemberian PMT maka asupan nutrisi ibu hamil dapat terpenuhi sehingga anak dapat terhindar dari stunting (Sri,2017). Hal ini juga didukung oleh pemerintah Indonesia dimana pemberian makanan tambahan kepada ibu hamil dicantumkan didalam kerangka intervensi stunting di Indonesia. ${ }^{26}$

Menurut Delmi Sulastri (2012) pengetahuan gizi yang rendah dapat menghambat usaha perbaikan gizi yang baik pada keluarga maupun masyarakat. Tingkat pengetahuan yang dimiliki oleh seseorang tentang kebutuhan akan zat-zat gizi berpengaruh terhadap jumlah dan jenis bahan makanan yang dikonsumsi. Pengetahuan gizi merupakan salah satu faktor yang dapat berpengaruh terhadap konsumsi pangan dan status gizi. Ibu yang cukup pengetahuan gizinya akan memperhatikan kebutuhan gizi anaknya agar dapat tumbuh dan berkembang secara optimal. ${ }^{4}$ Hal ini didukung penelitian FO Aridiyah (2015) yang menyatakan bahwa pengetahuan ibu tentang gizi merupakan salah satu factor yang mempengaruhi kejadian stunting pada anak balita diwilayah pedesaan dan perkotaan. ${ }^{6}$ Demikian juga penelitian Khoirun Ni'mah (2015) menyatakan bahwa pengetahuan ibu tentang gizi merupakan factor yang berhubungan dengan kejadian stunting pada balita. ${ }^{12}$

Balita dari keluarga dengan jumlah anggota rumah tangga banyak cenderung mengalami stunting dibandingkan balita dari keluarga dengan jumlah anggota rumah tangga cukup. Balita dari keluarga dengan jumlah anggota rumah tangga banyak lebih berisiko 1.34 kali mengalami stunting dibandingkan dengan balita dari keluarga dengan jumlah anggota rumah tangga cukup. Hal ini sesuai dengan hasil penelitian Zilda Oktarina dkk (2013) dimana hasil penelitiannya menyatakan faktor dominan yang berhubungan dengan kejadian stunting pada balita adalah jumlah anggota rumah tangga. Keluarga disarankan agar membatasi jumlah anak sesuai dengan program Keluarga Berencana (KB). Tshwane University (2006) dalam penelitiannya juga menemukan adanya hubungan besar keluarga dengan kejadian stunting pada balita. Anak-anak stunting berasal dari keluarga yang memiliki jumlah anggota rumah tangga lebih banyak dibandingkan dengan anakanak normal. ${ }^{30}$

Berdasarkan hasil survey yang dilakukan terhadap 8 orang ibu yang memiliki Balita di Desa Hiliweto Idanoi ditemukan data mayoritas ibu berpendapatan rendah, mayoritas bekerja sebagai tani, mayoritas berpendidikan rendah, ibu mayoritas berumur dewasa saat menikah, mayoritas mendapatkan makanan tambahan saat hamil, mayoritas memiliki pengetahuan kurang tentang gizi dan mayoritas memiliki jumlah anak banyak.

Berdasarkan permasalahan tersebut diatas maka peneliti tertarik untuk melakukan penelitian yang berjudul Hubungan Sosial Ekonomi dan Karakteristik Ibu Dengan Kejadian Stunting Pada Anak Balita di Desa Hiliweto Idanoi Wilayah Kerja UPTD Puskesmas Kecamatan Gunungsitoli Idanoi tahun 2020.

\section{Tujuan Penelitian (Opsional)}

Tujuan dalam penelitian ini terbagi dua yaitu tujuan umum dan tujuan khusus. Tujuan umum dari penelitian ini adalah untuk menganalisis hubungan sosial ekonomi dan karakteristik ibu dengan kejadian stunting pada anak balita didesa Hiliweto Idanoi wilayah kerja UPTD Puskesmas Gunungsitoli Idanoi Tujuan khusus dari penelitian ini adalah untuk menganalisis hubungan pendapatan dengan kejadian stunting, untuk menganalisis hubungan pekerjaan dengan kejadian stunting, untuk menganalisis hubungan pendidikan dengan kejadian stunting, untuk menganalisis hubungan umur dengan kejadian stunting, untuk menganalisis hubungan pengetahuan dengan kejadian stunting, untuk menganalisis hubungan jumlah anak dengan kejadian stunting dan untuk menganalisis hubungan pemberian makanan tambahan dengan kejadian stunting pada anak Balita tahun 2020.

\section{METODE \\ Jenis dan Rancangan Penelitian}

Penelitian ini merupakan Penelitian Kuantitatif dengan desain crossectional. Menurut Sugiyono metode penelitian kuantitatif dapat diartikan sebagai metode penelitian yang berlandaskan pada filsafat positivisme, digunakan untuk meneliti pada populasi atau sampel tertentu, teknik pengambilan sampel pada 
umumnya dilakukan secara random, pengumpulan data menggunakan instrument penelitian, analisis data bersifat kuantitatif/ statistic dengan tujuan untuk menguji hipotesis yang telah ditetapkan. Penelitian ini menggunakan desain cross sectional. $^{24}$ Menurut Notoatmodjo (2012) cross sectional adalah suatu penelitian untuk mempelajari suatu dinamika korelasi antara faktor - faktor resiko dengan efek, dan dengan suatu pendekatan, observasi ataupun dengan pengumpulan data pada suatu saat tertentu (point time approach). ${ }^{15}$

\section{Waktu dan Tempat Penelitian}

Penelitian ini dilaksanakan pada bulan September tahun 2020 di desa Hiliweto Idanoi yang merupakan wilayah kerja UPTD Puskesmas Kecamatan Gunungsitoli Idanoi.

\section{Populasi dan Sampel}

Populasi penelitian adalah seluruh ibu yang memiliki balita di desa Hiliweto Idanoi wilayah kerja UPTD Puskesmas Kecamatan Gunungsitoli Idanoi sebanyak 63 orang. Teknik pengambilan sampel dalam penelitian ini adalah total sampling, sehingga seluruh populasi menjadi sampel yaitu sebesar 63 orang.

\section{Variabel Penelitian}

Variabel dependent dalam penelitian ini adalah kejadian stunting. Variabel independent dalam penelitian ini adalah sosial ekonomi meliputi pendapatan, pekerjaan, pendidikan dan karakteristik ibu meliputi umur, pengetahuan, jumlah anak, pemberian makanan tambahan.

\section{Teknik Pengumpulan Data}

Data primer dalam penelitian ini adalah identitas responden, data sosial ekonomi, data karakteristik ibu yang diperoleh dengan wawancara dengan menggunakan kuesioner dan data tinggi badan balita diperoleh dengan mengukur tinggi badan balita menggunakan microtoise. Data sekunder diperoleh dari profil kesehatan Puskesmas dab Dinas Kesehatan berupa data jumlah balita dan status gizi balita di Puskesmas Kecamatan Gunungsitoli Idanoi.

\section{Pengolahan Data dan Analisis Data}

Data yang dianalisis akan diolah terlebih dahulu dimana kegiatannya terdiri dari: editing, scoring, coding, entery data dan tabulating. Data secara keseluruhan dianalisis dengan menggunakan program SPSS meliputi analisis univariat dan analisis bivariate. Adapun analisa statistic menggunakan uji chi-square.

\section{Kalayakan Etik}

Penelitian ini telah mendapatkan ethical clearance dari Komisi Etik Penelitian Kesehatan dengan nomor surat : 01/040/KEPK/POLTEKKES KEMENKES MEDAN 2020.

HASIL

\section{Analisis Univariat}

Berdasarkan dari hasil penelitian diperolah data mayoritas ibu balita berpenghasilan rendah yaitu sebesar 43 orang $(68,3 \%)$ dan minoritas ibu balita berpenghasilan menengah yaitu sebesar 20 orang (31,7 $\%$ ), mayoritas ibu balita bekerja yaitu sebesar 53 orang $(84,1 \%$ ) dan minoritas ibu balita tidak bekerja yaitu sebanyak sebesar 10 orang ( $15,9 \%)$, mayoritas ibu berpendidikan rendah yaitu sebanyak 37 orang ( 58, 7 $\%$ ) dan minoritas ibu berpendidikan tinggi yaitu sebanyak 2 orang ( $3,2 \%$ ), mayoritas ibu memiliki jumlah anak sedikit yaitu sebanyak 41 orang (65, $1 \%$ ) dan minoritas ibu memiliki jumlah anak banyak yaitu sebanyak 3 orang ( 4, $8 \%$ ), mayoritas ibu berumur dewasa/ matang yaitu sebanyak 61 orang ( 96,8 \% ) dan minoritas ibu berumur belum dewasa/matang yaitu sebanyak 2 orang ( $3,2 \%)$, mayoritas ibu berpengetahuan cukup yaitu sebanyak 45 orang (71,4 $\%$ ) dan minoritas ibu berpengetahuan baik yaitu sebanyak 4 orang ( 6,3\%). Mayoritas ibu diberikan makanan tambahan yaitu sebanyak 53 orang ( 84, $1 \%$ ) dan minoritas ibu tidak diberikan makanan tambahan yaitu sebanyak 10 (15,9\%), mayoritas Balita tidak stunting yaitu sebanyak 45 orang ( $71,4 \%)$ dan minoritas Balita Stunting yaitu sebanyak 18 orang ( $28,6 \%)$.

Tabel 1.

Distribusi Frekuensi Pendapatan, Pendidikan,

Pekerjaan, Umur, Jumlah Anak, Pengetahuan, Pemberian Makanan Tambahan

\begin{tabular}{|c|c|c|}
\hline Variabel & $\mathrm{N}$ & $\%$ \\
\hline \multicolumn{3}{|l|}{ Pendapatan } \\
\hline Pendapatan Rendah & 43 & 68,3 \\
\hline Pendapatan Menengah & 20 & 31,7 \\
\hline \multicolumn{3}{|l|}{ Pekerjaan } \\
\hline Tidak Bekerja & 10 & 15,9 \\
\hline Bekerja & 53 & 84,1 \\
\hline \multicolumn{3}{|l|}{ Pendidikan } \\
\hline Pendidikan Rendah & 37 & 58,7 \\
\hline Pendidikan Menengah & 24 & 38,1 \\
\hline Pendidikan Tinggi & 2 & 3,2 \\
\hline \multicolumn{3}{|l|}{ Jumlah Anak } \\
\hline Sedikit & 41 & 65,1 \\
\hline Sedang & 19 & 30,2 \\
\hline Banyak & 3 & 4,8 \\
\hline \multicolumn{3}{|l|}{ Umur } \\
\hline Belum dewasa & 2 & 3,2 \\
\hline Dewasa & 61 & 96,8 \\
\hline \multicolumn{3}{|l|}{ Pengetahuan } \\
\hline Kurang & 14 & 22,2 \\
\hline Cukup & 45 & 71,4 \\
\hline Baik & 4 & 6,3 \\
\hline \multicolumn{3}{|l|}{ Pemberian Makanan } \\
\hline \multicolumn{3}{|l|}{ Tambahan } \\
\hline Tidak diberikan PMT & 10 & 15,9 \\
\hline Diberikan PMT & 53 & 84,1 \\
\hline \multicolumn{3}{|l|}{ Kejadian Stunting } \\
\hline Tidak Stunting & 45 & $\begin{array}{l}71,4 \\
28,4\end{array}$ \\
\hline
\end{tabular}


Stunting 18

\section{Analisis Bivariat}

Berdasarkan hasil uji bivariate menggunakan chi square maka diperoleh hasil nilai significancy nya adalah 0,001 , dimana $\mathrm{p}<0,05$ artinya terdapat hubungan yang bermakna antara pendapatan dengan kejadian stunting pada anak balita di Desa Hiliweto Idanoi Wilayah Kerja UPTD Puskesmas Idanoi tahun 2020, diperoleh nilai significancy nya adalah 0,025 , dimana $\mathrm{p}<0,05$ artinya terdapat hubungan yang bermakna antara pekerjaan dengan kejadian stunting pada anak balita di Desa Hiliweto Idanoi Wilayah Kerja UPTD Puskesmas Idanoi tahun 2020, diperoleh nilai significancy nya adalah 0,418 , dimana $p>0,05$ artinya tidak terdapat hubungan yang bermakna antara pendidikan dengan kejadian stunting pada anak balita di Desa Hiliweto Idanoi Wilayah Kerja UPTD Puskesmas Idanoi tahun 2020, diperoleh nilai significancy nya adalah 0,493 , dimana $p>0,05$ artinya tidak terdapat hubungan yang bermakna antara umur dengan kejadian stunting pada anak balita di Desa Hiliweto Idanoi Wilayah Kerja UPTD Puskesmas Idanoi tahun 2020, diperoleh nilai significancy nya adalah 0,030 , dimana $\mathrm{p}<0,05$ artinya terdapat hubungan yang bermakna antara jumlah anak dengan kejadian stunting pada anak balita di Desa Hiliweto Idanoi Wilayah Kerja UPTD Puskesmas Idanoi tahun 2020, diperoleh nilai significancy nya adalah 0,197, dimana $\mathrm{p}>0,05$ artinya tidak terdapat hubungan yang bermakna antara pengetahuan dengan kejadian stunting pada anak balita di Desa Hiliweto Idanoi Wilayah Kerja UPTD Puskesmas Idanoi tahun 2020, diperoleh nilai significancy nya adalah 0,000 , dimana $\mathrm{p}<0,05$ artinya terdapat hubungan yang bermakna antara PMT dengan kejadian stunting pada anak balita di Desa Hiliweto Idanoi Wilayah Kerja UPTD Puskesmas Idanoi tahun 2020.
Tabel 2.

Hasil analisis hubungan pendidikan, pekerjaan, pendapatan, umur, pengetahuan, jumlah anak dan pemberian makanan tambahan dengan kejadian stunting pada anak balita

\begin{tabular}{|c|c|c|c|c|c|c|}
\hline \multirow[t]{3}{*}{ Variabel } & \multicolumn{4}{|c|}{$\begin{array}{l}\text { Kejadian Stunting } \\
\text { Pada Anak Balita }\end{array}$} & \multirow{3}{*}{$\begin{array}{l}\mathrm{T} \\
\text { ot } \\
\text { al }\end{array}$} & \multirow{3}{*}{$\begin{array}{c}\mathrm{P} \\
\text { Value }\end{array}$} \\
\hline & \multicolumn{2}{|c|}{$\begin{array}{c}\text { Tidak } \\
\text { Stunting }\end{array}$} & \multicolumn{2}{|c|}{ Stunting } & & \\
\hline & $\mathrm{n}$ & $\%$ & $\mathrm{n}$ & $\%$ & & \\
\hline \multicolumn{7}{|c|}{ Pendapatan } \\
\hline Rendah & 25 & 39,7 & 18 & 28,6 & 43 & 0,001 \\
\hline Menengah & 20 & 31,7 & 0 & 0 & 20 & \\
\hline \multicolumn{7}{|l|}{ Pekerjaan } \\
\hline $\begin{array}{l}\text { Tidak } \\
\text { Bekerja }\end{array}$ & 10 & 15,9 & 0 & 0 & 10 & 0,025 \\
\hline Bekerja & 35 & 55,5 & 18 & 28,6 & 53 & \\
\hline \multicolumn{7}{|l|}{ Pendidikan } \\
\hline Rendah & 25 & 39,7 & 12 & 19,1 & 37 & 0,418 \\
\hline $\begin{array}{l}\text { Menengah } \\
\text { Umur }\end{array}$ & 20 & 31,7 & 6 & 9,5 & 26 & \\
\hline $\begin{array}{l}\text { Belum } \\
\text { Dewasa }\end{array}$ & 1 & 1,6 & 1 & 1,6 & 2 & 0,493 \\
\hline Dewasa & 44 & 69,8 & 17 & 27 & 61 & \\
\hline \multicolumn{7}{|c|}{ Jumlah Anak } \\
\hline Sedikit & 33 & 52,4 & 8 & 12,7 & 41 & 0,030 \\
\hline Sedang & 12 & 19 & 10 & 15,9 & 22 & \\
\hline \multicolumn{7}{|c|}{ Pengetahuan } \\
\hline $\begin{array}{l}\text { Kurang } \\
\text { Cukup }\end{array}$ & $\begin{array}{l}8 \\
37\end{array}$ & $\begin{array}{l}12,7 \\
58,7\end{array}$ & $\begin{array}{c}6 \\
12\end{array}$ & $\begin{array}{c}9,5 \\
19,1\end{array}$ & $\begin{array}{l}14 \\
49\end{array}$ & 0,197 \\
\hline $\begin{array}{l}\text { PMT } \\
\text { Tidak } \\
\text { diberikan } \\
\text { MT }\end{array}$ & 1 & 1,6 & 9 & 14,3 & 10 & 0,000 \\
\hline $\begin{array}{l}\text { Diberikan } \\
\text { MT }\end{array}$ & 44 & 69,8 & 9 & 14,3 & 53 & \\
\hline
\end{tabular}

\section{PEMBAHASAN}

Berdasarkan hasil penelitian diketahui bahwa terdapat hubungan yang bermakna antara pendapatan dengan kejadian stunting pada anak balita di Desa Hiliweto Idanoi Wilayah Kerja UPTD Puskesmas Idanoi tahun 2020. Pendapatan keluarga berkaitan 
dengan kemampuan rumah tangga tersebut dalam memenuhi kebutuhan hidup baik primer, sekunder, maupun tersier. Pendapatan keluarga yang tinggi memudahkan dalam memenuhi kebutuhan hidup, sebaliknya pendapatan keluarga yang rendah lebih mengalami kesulitan dalam memenuhi kebutuhan hidup. Pendapatan yang rendah akan mempengaruhi kualitas maupun kuantitas bahan makanan yang dikonsumsi oleh keluarga. Makanan yang di dapat biasanya akan kurang bervariasi dan sedikit jumlahnya terutama pada bahan pangan yang berfungsi untuk pertumbuhan anak seperti sumber protein, vitamin, dan mineral, sehingga meningkatkan risiko kurang gizi. Keterbatasan tersebut akan meningkatkan risiko seorang balita mengalami stunting ${ }^{29}$. Hal ini sesuai dengan penelitian yang dilakukan oleh Eko dkk (2018) dimana hasil penelitian menyatakan bahwa ada hubungan tingkat pendapatan keluarga dengan kejadian stunting. ${ }^{5}$ Demikian juga hasil penelitian Delmi sulastri (2012) yang menyatakan bahwa tingkat ekonomi mempengaruhi kejadian stunting. ${ }^{4} \mathrm{Hal}$ ini juga didukung oleh penelitian Khoirun Ni'mah dkk (2015) dimana hasil penelitiannya menyatakan bahwa pendapatan keluarga yang rendah merupakan faktor yang berhubungan dengan kejadian stunting pada balita. $^{12}$

Berdasarkan hasil penelitian diketahui bahwa terdapat hubungan yang bermakna antara pekerjaan dengan kejadian stunting pada anak balita di Desa Hiliweto Idanoi Wilayah Kerja UPTD Puskesmas Idanoi tahun 2020. Menurut UNICEF dalam BAPPENAS (2011), pekerjaan orang tua merupakan faktor tidak langsung yang mempengaruhi stunting. ${ }^{23}$ Faktor ibu yang bekerja nampaknya belum berperan sebagai penyebab utama masalah gizi anak, namun pekerjaan ini lebih disebut sebagai faktor yang mempengaruhi dalam pemberian makanan, zat gizi, dan pengasuhan/perawatan anak (Suhardjo, 1992). Ibu yang bekerja diluar rumah cenderung memiliki waktu yang lebih terbatas untuk melaksanakan tugas rumah tangga dibandingkan ibu yang tidak bekerja, oleh karena itu pola pengasuhan anak akan berpengaruh dan pada akhirnya pertumbuhan dan perkembangan anak juga akan terganggu. ${ }^{12} \mathrm{Hal}$ ini sesuai dengan penelitian yang dilakukan oleh Sri Mugianti (2018) dimana hasil penelitiannya menyatakan bahwa ibu bekerja merupakan salah satu faktor penyebab stunting ${ }^{23}$.

Berdasarkan hasil penelitian diketahui bahwa terdapat hubungan yang bermakna antara jumlah anak dengan kejadian stunting pada anak balita di Desa Hiliweto Idanoi Wilayah Kerja UPTD Puskesmas Idanoi tahun 2020. Balita dari keluarga dengan jumlah anggota rumah tangga banyak cenderung mengalami stunting dibandingkan balita dari keluarga dengan jumlah anggota rumah tangga cukup. Balita dari keluarga dengan jumlah anggota rumah tangga banyak lebih berisiko 1.34 kali mengalami stunting dibandingkan dengan balita dari keluarga dengan jumlah anggota rumah tangga cukup. Hal ini sesuai dengan hasil penelitian Zilda Oktarina dkk (2013) dimana hasil penelitiannya menyatakan faktor dominan yang berhubungan dengan kejadian stunting pada balita adalah jumlah anggota rumah tangga. Keluarga disarankan agar membatasi jumlah anak sesuai dengan program Keluarga Berencana (KB). Tshwane University (2006) dalam penelitiannya juga menemukan adanya hubungan besar keluarga dengan kejadian stunting pada balita. Anak-anak stunting berasal dari keluarga yang memiliki jumlah anggota rumah tangga lebih banyak dibandingkan dengan anakanak normal. ${ }^{30}$

Berdasarkan hasil penelitian diketahui bahwa terdapat hubungan yang bermakna antara PMT dengan kejadian stunting pada anak balita di Desa Hiliweto Idanoi Wilayah Kerja UPTD Puskesmas Idanoi tahun 2020. Pemberian makanan tambahan kepada ibu hamil merupakan salah satu cara untuk mengatasi kekurangan energi dan protein kronis yang dapat mengakibatkan pertumbuhan fisik balita pendek (stunting). Dengan pemberian PMT maka asupan nutrisi ibu hamil dapat terpenuhi sehingga anak dapat terhindar dari stunting. ${ }^{22} \mathrm{Hal}$ ini juga didukung oleh pemerintah Indonesia dimana pemberian makanan tambahan kepada ibu hamil dicantumkan didalam kerangka intervensi stunting di Indonesia. ${ }^{26}$

Berdasarkan hasil penelitian diketahui bahwa

tidak terdapat hubungan yang bermakna antara pendidikan dengan kejadian stunting pada anak balita di Desa Hiliweto Idanoi Wilayah Kerja UPTD Puskesmas Idanoi tahun 2020. Hal ini sesuai dengan penelitian yang dilakukan oleh Nimah (2015) dimana hasil penelitiannya menyatakan bahwa tidak ada hubungan pendidikan dengan kejadian stunting, hal ini dikarenakan banyaknya faktor yang menyebabkan stunting.

Berdasarkan hasil penelitian diketahui bahwa artinya tidak terdapat hubungan yang bermakna antara umur dengan kejadian stunting pada anak balita di Desa Hiliweto Idanoi Wilayah Kerja UPTD Puskesmas Idanoi tahun 2020. Hal ini sesuai dengan hasil penelitian Agustiningrum ( 2016 ) yang menyatakan bahwa tidak ada hubungan antara usia ibu dengan kejadian stunting pada anak balita usia 24 -59 bulan di wilayah kerja Puskesmas Wonosiri I dan usia bukan merupakan faktor resiko kejadian stunting. Hal ini juga sejalan dengan hasil penelitian yang telah dilakukan oleh Astuti (2016) yang menyatakan bahwa tidak terdapat hubungan antara usia ibu dengan kejadian stunting. Hal ini dikarenakan usia ibu dianggap lebih berperan sebagai faktor psikologis ibu seperti penerimaan kehamilan anak sehingga berpengaruh terhadap pola pengasuhan anak, dalam hal ini pola asuh pemberian makanan.

Berdasarkan hasil penelitian diketahui bahwa tidak terdapat hubungan yang bermakna antara pengetahuan dengan kejadian stunting pada anak balita di Desa Hiliweto Idanoi Wilayah Kerja UPTD Puskesmas Idanoi tahun 2020. Hal ini sesuai dengan 
penelitian yang dilakukan oleh Salman (2017) yang menyatakan bahwa tidak ada hubungan antara pengetahuan gizi ibu dengan kejadian stunting pada balita. Hal ini disebabkan oleh banyak faktor yang menyebabkan kejadian stunting pada anak.

\section{KESIMPULAN}

Berdasarkan hasil penelitian yang telah dilakukan mengenai hubungan sosial ekonomi dan karakteristik ibu dengan kejadian stunting pada anak balita di desa Hiliweto Idanoi wilayah kerja UPTD Puskesmas Kecamatan Gunungsitoli Idanoi Tahun 2020, maka dapat disimpulkan bahwa terdapat hubungan pendapatan, pekerjaan, jumlah anak dan pemberian makanan tambahan dengan kejadian stunting pada anak balita di desa Hiliweto Idanoi wilayah kerja UPTD Puskesmas Kecamatan Gunungsitoli Idanoi tahun 2020 dan tidak terdapat hubungan pendidikan, umur, pengetahuan dengan kejadian stunting pada anak balita di desa Hiliweto Idanoi wilayah kerja UPTD Puskesmas Kecamatan Gunungsitoli Idanoi tahun 2020.

\section{DAFTAR PUSTAKA}

1. Arikunto S. Prosedur Penelitian Suatu Pendekatan Praktik. Jakarta. Rineka Cipta ; 2010.

2. Cholifatun N. Hubungan Tingkat Pendidikan , Tingkat Pengetahuan dan Pola Asuh Ibu Dengan Wasting dan Stunting Pada Balita Keluarga Miskin. Media Gizi Indonesia ; 2015. Vol.1 (No.1).84 - 90.

3. Devi N. Nutrition and Food. Jakarta. Kompas ; 2010.

4. Delmi S. Faktor Determinan Kejadian Stunting Pada Anak Usia Sekolah Di Kecamatan Lubuk Kilangan Kota Padang. Majalah Kedokteran Andalas ; 2012. Vol 36(no.1).39 - 50.

5. Eko S, Rizanda M, Masrul. Faktor-Faktor yang Berhubungan dengan Kejadian Stunting pada Anak Usia 24-59 Bulan di Wilayah Kerja Puskesmas Andalas Kecamatan Padang Timur Kota Padang Tahun 2018. Jurnal kesehatan Andalas; 2018. 275 -284 .

6. Farah OA, Ninna R ,Murry R. Faktor-faktor yang Mempengaruhi Kejadian Stunting pada Anak Balita di Wilayah Pedesaan dan Perkotaan; 2015. eJurnal Pustaka Kesehatan, vol. 3 (no. 1).

7. Kementerian Desa,Pembangunan Daerah Tertinggal,Dan Transmigrasi. Buku Saku Desa Dalam Penanganan Stunting. Jakarta:Kementerian Desa,Pembangunan Daerah Tertinggal Dan Transmigrasi; 2017.
8. Kementerian Kesehatan RI. Standar Antropometri Penilaian Status Gizi Anak. Jakarta: Kementerian Kesehatan RI; 2014.

9. Kementerian Kesehatan RI. Profil Kesehatan Indonesia tahun 2018, Kementrian Kesehatan Republik Indonesia; 2019 ( diakses tanggal 2 Oktober 2019) melalui http://www.depkes.go.id/resources/download/pusd atin/profil-kesehatan-indonesia/profil-kesehatanindonesia-2018.pdf).

10. Kementerian Kesehatan RI. Profil Kesehatan Propinsi Sumatera Utara tahun 2017, Dinas Kesehatan Propinsi Sumatera Utara; 2018 (diakses tanggal 2 Oktober 2019) melalui (http://www.depkes.go.id/resources/download/prof il/PROFIL_KES_PROVINSI_2017/02_Sumut_20 17.pdf

11. Dinas Kesehatan Kota Gunungsitoli, Profil Kesehatan Kota Gunungsitoli Tahun 2019. Gunungsitoli; Dinas Kesehatan Kota Gunungsitoli;2019

12. Khoirun NM, Nadhiroh SR. Faktor yang Berhubungan dengan Kejadian Stunting Pada Balita. Media Gizi Indonesia; 2015. 10 (1): 16-17.

13. Luh MM. Hubungan Pengetahuan Ibu Tentang Gizi Balita Dengan Kejadian Stunting Anak Umur 36 59 Bulan Di Desa Singakerta Kabupaten Gianyar. Poltekkes Denpasar ; 2018.

14. Mustamin.Tingkat Pendidikan Ibu Dan Pemberian ASI Eksklusif Dengan Kejadian Stunting Pada Balita Di Provinsi Sulawesi Selatan.Media Gizi Pangan; 2018. Vol.25. Edisi 1. 25 -32.

15. Notoadmodjo S. Metodologi Penelitian Pengetahuan, Sikap, dan Perilaku Manusia. Yogyakarta: Nuha Medika; 2010.

16. Notoatmodjo S. Ilmu Perilaku Kesehatan. Jakarta: Rineka Cipta; 2014.

17. Nur.A (2017). Hubungan Usia Ibu Menikah Dini Dengan Status Gizi Batita Di Kabupaten Temanggung. Journal of Nutrition College; 2017. Volume 6. No.1.1 - 10.

18. Pusat Data dan Informasi. Situasi Balita Pendek (Stunting) di Indonesia, Semester 1,Jakarta: Kementrian Kesehatan RI; 2018.

19. Putri DS, Sukandar D. Keadaan Rumah, Kebiasaan Makan, Status Gizi, Dan Status Kesehatan Balita di Kecamatan Tamansari, Kabupaten Bogor; Jurnal Gizi Pangan; 2012. Vol. 7, No.3; 163 - 168.

20. Sandra, F., Syafiq, A., Veratamala, A. Gizi Anak dan Remaja. Depok. Rajawali Pers; 2017. 
21. Santoso S, Ranti AL. Kesehatan dan Gizi. Jakarta: Rineka Cipta; 2009.

22.Sri . Pengaruh Pemberian Biskuit Makanan Tambahan (MT) Terhadap Peningkatan Berat Badan, Kadar Hemoglobin (Hb) dan Albumin Pada Ibu Hamil Kurang Energi Kronis Yang Mendapat Tablet Tambah Darah (IFA).Thesis. Universitas Hasanudin; 2017.

23. Sri M. Faktor penyebab anak Stunting usia 25-60 bulan di Kecamatan Sukorejo Kota Blitar. Jurnal Ners dan Kebidanan; 2018.Vol 5.No.3. 268 - 278.

24. Sugiyono. Metodologi Penelitian Kuantitatif, Kualitatif Dan R\&D. Bandung: ALFABETA; 2013.

25. Sugiyono. Metode Penelitian Kuantitatif, Kualitatif, dan R\&D. Bandung . Alfabeta; 2017.

26. Tim Nasional Percepatan Penanggulangan Kemiskinan. 100 Kabupaten/Kota Prioritas Untuk Intervensi Anak Kerdil (stunting), Cetakan Pertama, Jakarta Utara: Sekretariat Wakil Presiden Republik Indonesia ; 2017.

27. Trihono., Atmarita., Tjandrarini DH, Irawati A., Utami NH, Tejayanti T , Nurlinawati I. Pendek (Stunting) di Indonesia, Masalah dan Solusinya. Jakarta: Badan Penelitian dan Pengembangan Kesehatan; 2015.

28. Wawan, Dewi M. Teori dan Pengukuran Pengetahuan, Sikap, dan Perilaku Manusia. Cetakan II. Yogyakarta: Nuha Medika; 2011.

29. Windi H. Hubungan Pendapatan Keluarga, Pengetahuan Ibu Tentang Gizi, Tingggi Badan Orang Tua, Dan Tingkat Pendidikan Ayah Dengan Kejadian Stunting Pada Anak Umur 12 - 59 Bulan. Skripsi. Universitas Muhammadiyah Surakarta; 2018.

30. Zilda O. Faktor Risiko Stunting Pada Balita (24 59 Bulan) Di Sumatera; 2013.JGP.Vol.8.No.3. 175 -180 . 